University of Nebraska - Lincoln

DigitalCommons@University of Nebraska - Lincoln

2017

\title{
Common Carp Disrupt Ecosystem Structure and Function Through Middle-out Effects
}

\author{
Mark A. Kaemingk \\ University of Nebraska - Lincoln, mkaemingk2@unl.edu \\ Jeffrey C. Jolley \\ South Dakota State University, jeffrey_jolley@fws.gov \\ Craig P. Paukert \\ University of Missouri \\ David W. Willis \\ South Dakota State University \\ Kjetil Henderson \\ United States Fish and Wildlife Service, Crab Orchard National Wildlife Refuge
}

See next page for additional authors

Follow this and additional works at: https://digitalcommons.unl.edu/natrespapers

Part of the Natural Resources and Conservation Commons, Natural Resources Management and Policy Commons, and the Other Environmental Sciences Commons

Kaemingk, Mark A.; Jolley, Jeffrey C.; Paukert, Craig P.; Willis, David W.; Henderson, Kjetil; Holland, Richard S.; Wanner, Greg A.; and Lindvall, Mark L., "Common Carp Disrupt Ecosystem Structure and Function Through Middle-out Effects" (2017). Papers in Natural Resources. 682.

https://digitalcommons.unl.edu/natrespapers/682

This Article is brought to you for free and open access by the Natural Resources, School of at DigitalCommons@University of Nebraska - Lincoln. It has been accepted for inclusion in Papers in Natural Resources by an authorized administrator of DigitalCommons@University of Nebraska - Lincoln. 


\section{Authors}

Mark A. Kaemingk, Jeffrey C. Jolley, Craig P. Paukert, David W. Willis, Kjetil Henderson, Richard S. Holland, Greg A. Wanner, and Mark L. Lindvall 


\title{
Common carp disrupt ecosystem structure and function through middle-out effects
}

\author{
Mark A. Kaemingk ${ }^{\mathrm{A}, \mathrm{I}}$, Jeffrey C. Jolley ${ }^{\mathrm{B}}$, Craig P. Paukert ${ }^{\mathrm{C}}$, David W. Willis ${ }^{\mathrm{H}}$, \\ Kjetil Henderson ${ }^{\mathrm{D}}$, Richard S. Holland ${ }^{\mathrm{E}}$, Greg A. Wanner ${ }^{\mathrm{F}}$ \\ and Mark L. Lindvall \\ A Department of Natural Resource Management, South Dakota State University, \\ Brookings, SD 57007, USA. \\ ${ }^{B}$ United States Fish and Wildlife Service, Columbia River Fisheries Program Office, \\ 1211 SE Cardinal Court, Vancouver, WA 98683, USA. \\ C United States Geological Survey, Missouri Cooperative Fish and Wildlife Research Unit, \\ Department of Fisheries and Wildlife Sciences, University of Missouri, \\ Columbia, MO 65211, USA. \\ DUnited States Fish and Wildlife Service, Crab Orchard National Wildlife Refuge, \\ Route 148, Marion, IL 62959, USA. \\ ENebraska Game and Parks Commission, PO Box 30370, Lincoln, NE 68701, USA. \\ FUSDA Forest Service, Mt Hood National Forest, Zigzag Ranger District, 70220 East Highway 26, \\ Zigzag, OR 97049, USA. \\ ${ }^{G}$ Valentine National Wildlife Refuge, 40811 Hackberry Drive, Valentine, NE 69201, USA. \\ ${ }^{H}$ Deceased. Formerly at Department of Natural Resource Management, South Dakota State \\ University, Brookings, SD 57007, USA. \\ 'Corresponding author. Present address. School of Natural Resources, \\ University of Nebraska-Lincoln, Lincoln, NE 68583, USA. Email: mkaemingk2@unl.edu
}

\begin{abstract}
Middle-out effects or a combination of top-down and bottom-up processes create many theoretical and empirical challenges in the realm of trophic ecology. We propose using specific autecology or species trait (i.e. behavioural) information to help explain and understand trophic dynamics that may involve complicated and nonunidirectional trophic interactions. The common carp (Cyprinus carpio) served as our model species for whole-lake observational and experimental studies; four trophic levels were measured to assess common carp-mediated middle-out effects across multiple lakes. We hypothesised that common carp could influence aquatic ecosystems through multiple pathways (i.e. abiotic and biotic foraging, early life feeding, nutrient). Both studies revealed most trophic levels were affected by common carp, highlighting strong middle-out effects likely caused by common carp foraging activities and abiotic influence (i.e. sediment resuspension). The loss of water transparency, submersed vegetation and a shift in zooplankton dynamics were the strongest effects. Trophic levels furthest from direct pathway effects were also affected (fish life history traits). The present study demonstrates that common carp can exert substantial effects on ecosystem structure and function. Species capable of middle-out effects can greatly modify communities through a variety of available pathways and are not confined to traditional top-down or bottom-up processes.
\end{abstract}

Additional keywords: food webs, ecosystem engineers, shallow lake ecosystems.

Received 20 February 2015, accepted 18 March 2016, published online 20 June 2016

\section{Introduction}

The concept of trophic cascades has been a cornerstone and one of the greatest breakthroughs in recent ecological studies for understanding energy flow and community dynamics, especially in aquatic ecosystems (Carpenter et al. 1985; Strong 1992; Pace et al. 1999). Yet, empirical information and ecological modelling have not always been congruent, despite gaining widespread interest, to capture this process. Attempts to address this misalignment has resulted in creating a series of feedback loops and the incorporation of food chain length and behavioural components (Schmitz et al. 1997). The primary framework of trophic cascades was guided by grouping species according to their respective feeding guilds and subsequent ecological impact (Carpenter and Kitchell 1988). Although simplistic and 
intuitive, this approach fails to consider species-specific functional traits or organismal performance metrics that affect cascade direction (e.g. top-down, bottom-up) and magnitude. Grouping species according to trophic position also fails to identify subwebs or weak and indirect links and the degree of effects within a series of reactions (Borer et al. 2005). Thus, a more refined understanding of trophic patterns and processes could be achieved by incorporating species-specific traits (DeAngelis 2013; van Veen and Sanders 2013).

Incorporating functional trait information is gaining widespread interest across ecological disciplines to explain ecosystem patterns and processes (de Bello et al. 2010; Morales-Castilla et al. 2015; Wood et al. 2015). Ecosystem function is a product of resource dynamics and ecosystem stability, which are strongly affected by individual species and interspecific relationships (Díaz and Cabido 2001). Therefore, species functional trait information could be a great tool to explain complex communityand ecosystem-level interactions within the realm of trophic cascades (Duffy et al. 2007), in addition to species richness and diversity metrics (Noss 1990). Certain species and associated traits can greatly affect resource availability and energy flow for other species (i.e. ecosystem engineers; Jones et al. 1994). Species that directly and indirectly modify habitat are particularly important to consider in a functional trait and ecosystem framework.

Species-specific trait information has already given promise and insight into understudied trophic cascade dynamics (Schmitz et al. 2004; Greeney et al. 2015). Middle-out effects, which do not conform strictly to a bottom-up or a top-down series of reactions (i.e. hybrid of the two), have been described for both freshwater and marine ecosystems (DeVries and Stein 1992; Allen and Fulton 2010). Multiple disturbance pathways exist and can often stem from one species, creating complex and unpredictable bottom-up and top-down effects (DeVries and Stein 1992; Jones et al. 1994; Wahl et al. 2011). For example, open water omnivores, such as the gizzard shad (Dorosoma cepedianum), can affect zooplankton, detritus and phytoplankton densities by direct consumption, subsequently reducing food availability for bluegill (Lepomis macrochirus) and largemouth bass (Micropterus salmoides), which depend on bluegill as prey (DeVries and Stein 1992; Stein et al. 1995). Middle-out patterns may manifest themselves through multiple pathways available (opposed to an alternating chain-like pathway for traditional trophic cascades; McQueen et al. 1986) and are dependent on habitat, community dynamics and individual species composition. This complexity may require a different approach to understand food webs and illuminate patterns and processes otherwise obscured with traditional trophic cascade thinking. Within a functional grouping, species traits can differ widely and, furthermore, at an interspecies level (DeAngelis 2013). Specific and broad information concerning species traits, such as foraging behaviour (van Veen and Sanders 2013), could strengthen the accuracy, precision and overall utility of food web and trophic ecology conceptual and quantitative models (Schmitz et al. 2004).

The aim of the present study was to investigate whether autecological traits could provide a more realistic approach to our understanding of trophic cascade ecology by using traits (such as behaviour) to guide the development of conceptual and quantitative models (particularly to explain middle-out effects). The benefits could reveal mechanisms relating to lag effects or delays in trophic-level response, how trophic interactions transpire and the proximity and resilience of multiple trophic levels to changes in ecosystem structure and function. We chose to address these trophic cascade questions using freshwater lakes and common carp (Cyprinus carpio), considering much of the early conceptual and empirical work was developed on these systems (Carpenter and Kitchell 1988; Pace et al. 1999). Common carp served as our focal species to test for middleout effects and to evaluate how acknowledging species traits (e.g. behaviour) could improve the interpretation of trophic patterns and processes (Fig. 1). For example, common carp foraging behaviour can result in mobilising nutrients (bottom-up) and the reduction of macroinvertebrate densities (top-down). Without incorporating this and other species trait information, it is difficult to understand trophic relationships and effects. Common carp are considered ecosystem engineers (Jones et al. 1994; Parkos et al. 2003; Matsuzaki et al. 2009) because of their inferred ability to affect aquatic systems (i.e. modify habitats) through middle-out effects (Richardson et al. 1990; Wahl et al. 2011), although limited information has been obtained at the ecosystem level (e.g. lake; Weber and Brown 2009; Vilizzi et al. 2015).

The present study used both observational and experimental techniques at a whole-lake ecosystem level to investigate complex middle-out trophic effects. Four identified common carp disturbance pathways were developed from the existing literature and evaluated. These pathways included an adult abiotic, early life feeding, adult biotic and an adult nutrient pathway (see Fig. 1). The study was designed to test the relative support for each pathway, because it is often unclear which mechanism is primarily responsible despite clear patterns or outcomes. Common carp benthic foraging often results in increased water turbidity. However, multiple trophic levels must be examined in concert at the appropriate scale to detect causation and ultimately unravel the mechanisms (or variables) involved. Turbidity may increase, but several indirect or direct pathways exist to reach this outcome. Our goal was to gain more insight to this complex middle-out process by empirically testing each pathway at the ecosystem level rather than at a reduced spatial or temporal scale, as recommended by Vilizzi et al. (2015).

\section{Materials and methods}

All work described herein was approved by the South Dakota State University Institutional Animal Care and Use Committee (\#08-A021).

\section{Study area and metric selection}

All lakes sampled were natural and part of the Sandhill ecoregion in north central Nebraska (USA). These lakes depend on groundwater and surface water drainage, with many having flowing springs and seepages. Although the lakes may have 2-3 months of ice cover, winterkills are limited (McCarraher 1977). The observational component included 16 lakes with similar fish assemblages, except that eight lakes contained common carp and eight did not; all lakes had a similar surface area 


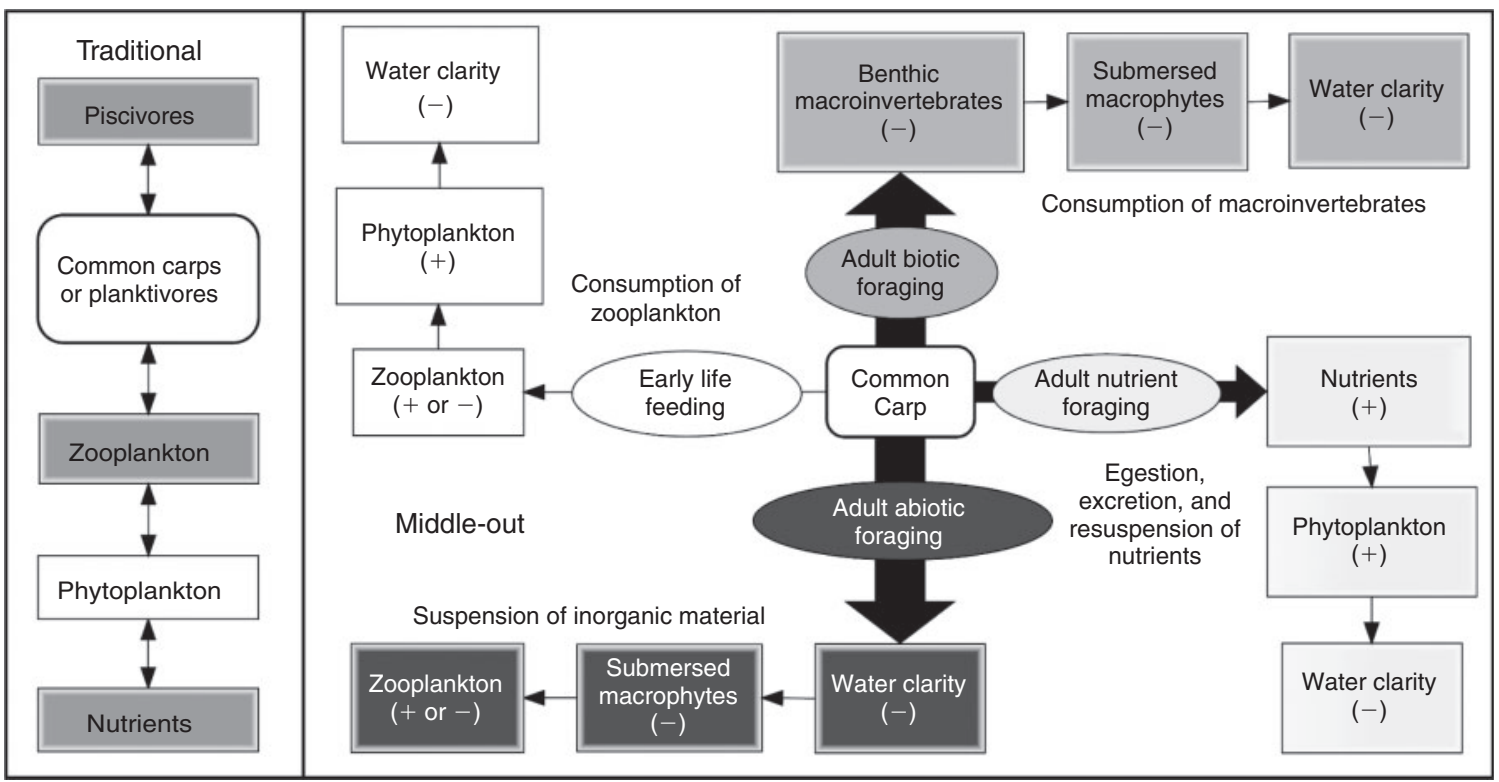

Fig. 1. A schematic demonstrating common carp trophic effects in a traditional (bottom-up, top-down; left) and middle-out (right) framework. A middle-out approach highlights (1) four potential common carp disturbance pathways; (2) direction and trophic position of the pathways; and (3) magnitude (arrow width stemming from common carp, with larger width reflecting a larger disturbance) and potential effect of disturbance (negative sign indicates a decrease; positive sign indicates an increase). Ovals represent the immediate activity and behaviour or process of common carp disturbance. For a summary and review, see Weber and Brown (2009) and Vilizzi et al. (2015).

(carp $v$. non-carp $F_{1,14}=1.28, P=0.28$, analysis of variance, ANOVA) and each lake was sampled once during 1998 or 1999 (see Table S1, available as Supplementary material to this paper) using conventional sampling gear (e.g. electrofishing; Bajer and Sorensen 2012). Common carp size and age structure were not measured across lakes, but rather their presence or absence was assessed. All variables from each lake were sampled concurrently except for vegetation (July 1999).

Two lakes were selected as part of the experimental component. Pony Lake (64 ha) served as the treatment lake and West Long Lake (25 ha) served as the reference lake. Pony Lake was dominated by common carp and existed in a turbid and limited submersed vegetation state (Kaemingk and Willis 2014). The fish community also included black bullhead (Ameiurus melas), fathead minnow (Pimephales promelas), golden shiner (Notemigonus crysoleucas), green sunfish (Lepomis cyanellus), pumpkinseed (Lepomis gibbosus), yellow perch (Perca flavescens) and grass pickerel (Esox americanus vermiculatus), but no top-level piscivores (e.g. largemouth bass or northern pike, Esox lucius). West Long Lake existed in a clear water and vegetated state; the fish community was comprised primarily of bluegill, yellow perch, black bullhead and two top-level piscivores, namely largemouth bass and northern pike (Jolley et al. 2008).

We selected important metrics according to previous studies (for a summary, see Weber and Brown 2009) across a range of lake trophic levels to identify bottom-up and top-down processes, investigating the relative support of each in a middle-out framework at the ecosystem level (Fig. 1). Wholelake middle-out effects were evaluated by comparing metrics across the food web (as in nutrients, phytoplankton, zooplankton, benthic macroinvertebrates) between lakes using common carp as the treatment (presence or absence) for the observational portion and the removal of common carp for the experimental portion of the study. In addition, representative fish from different trophic feeding guilds (bluegill, insectivore; yellow perch, lower level piscivore; and largemouth bass, higher level piscivore; Vander Zanden et al. 1997) were also evaluated using dynamic rate function responses (i.e. recruitment, growth and mortality) for the observational component.

\section{Observational approach \\ Bottom-up effects sampling}

Total phosphorous, Secchi disc transparency and chlorophyll- $a$ were measured at four random sites within each lake as metrics of primary productivity. Total phosphorus was measured with Hach kits (Hach, Loveland, CO, USA) and chlorophyll- $a$ was estimated from duplicate samples of four offshore water samples collected with a 2 m-long vertical tube sampler (Paukert and Willis 2003). Samples were filtered through glass fibre filters in the field and extracted in the laboratory by methods described by Lind (1979). Submersed vegetation was quantified for all 16 lakes at five to seven transects evenly spaced across each lake. At 50- to 200-m intervals (depending on lake size) along each transect, vegetation within a $1-\mathrm{m}^{2}$ grid beside the boat was classified as either emergent or submersed (Paukert et al. 2002a). The percentage coverage of submersed vegetation was calculated as the number of sites containing submersed vegetation divided by the total number of sites sampled across all transects in the lake (Paukert et al. 2002a). 


\section{Top-down effects sampling}

Zooplankton and benthic macroinvertebrates were sampled at the same four randomly selected sites in each of the 16 lakes examined (for detailed methods, see Paukert and Willis 2003), representing the available habitat in each lake. Concurrent zooplankton (two replicates) and benthic macroinvertebrates (three samples) were collected at each site. In the laboratory, zooplankton were enumerated and identified to Family for cladocerans (i.e. Bosminidae, Chydoridae and Daphnidae) and as cyclopoid or calanoid copepods and copepod nauplii. The total number of zooplankton of each taxon in a sample was calculated by dividing the number of organisms counted by the proportion of the sample volume processed. Density was then calculated by dividing the number of zooplankters of each taxon by the volume of the water filtered with the tube sampler. A maximum of 120 individuals of each zooplankton taxon was measured. Zooplankton taxon-specific length-dry weight conversions were used to convert length to biomass $\left(\mu \mathrm{g} \mathrm{L}^{-1}\right.$; Cummins and Wuycheck 1971; Dumont et al. 1975; Culver et al. 1985). Macroinvertebrates were identified to Order and counted. Density was then calculated by dividing the number of benthic invertebrates of each taxon by the area sampled with the Ekman grab.

Bluegill and yellow perch were sampled at randomly selected locations with 20 overnight sets per lake of double-throated trap nets (i.e. modified fyke nets) with $16-\mathrm{mm}$ bar measure mesh, $1.1 \times 1.5-\mathrm{m}$ frames and 22-m leads. Largemouth bass were sampled by pulsed direct current (DC; 200-250 V, 3-6 A) night-time boat electrofishing at 12 randomly selected 10-min stations, in May or June. Scales for age and growth analyses were collected from bluegill, yellow perch and largemouth bass (Paukert et al. 2002b). A total of 10 individuals was aged per $1.0-\mathrm{cm}$ length group of each species per lake. Mean length at age for all species was fitted to a non-linear least-squares regression model (assuming additive errors) with the von Bertalanffy growth function (Ricker 1975). Models were then used to estimate growth as the time in years for each species to reach preferred lengths (bluegill $200 \mathrm{~mm}$, yellow perch $250 \mathrm{~mm}$, largemouth bass $380 \mathrm{~mm}$; Gabelhouse 1984). Total instantaneous mortality (Z) was estimated from the descending limb of catch curves for each population (Ricker 1975). A recruitment variability index (RVI) allowed the estimation of variability in recruitment among lakes with and without common carp for each species (Guy and Willis 1995). Estimates for the recruitment variability index ranged from -1 to 1 , with increasing values indicating less recruitment variability (i.e. consistent).

\section{Statistical analysis}

ANOVA (PROC MIXED method in SAS, ver. 9.3; SAS Institute, Cary, NC, USA), was used to determine whether bottom-up effects (i.e. total phosphorus, Secchi disc transparency, submersed vegetation and chlorophyll-a), top-down effects (i.e. zooplankton, benthic macroinvertebrates, and fish recruitment, growth and mortality) were evident between lakes with and without common carp. Data were $\log$ transformed $\left(\log _{10}[\mathrm{~N}+1]\right)$ when necessary to achieve normality and homogeneity of variance. Differences in treatment means were assessed at $\alpha \leq 0.10$ to guard against a Type II error. We considered a Type II error more probable because no treatment or variable was applied or manipulated in this portion of the study (Mapstone 1995).

Four common carp disturbance pathways were compared and evaluated using an information theoretic approach (Akaike's information criterion (AIC); Burnham and Anderson 2002). Model weights were calculated by taking the relative likelihood of a model and dividing that number by the summation of all model relative likelihoods. The sum of all model weights within a candidate set is equal to 1 , with each model given a value between 0 and 1 . The highest Akaike weight among the candidate set of models can be interpreted as the percentage chance that it is the best approximating model (among all models considered). Model disturbance pathways included an adult abiotic, early life feeding, adult biotic and an adult nutrient pathway (see Fig. 1). Logistic regression models (Proc Logistic method in SAS, ver, 9.3; SAS Institute) were developed using the presence or absence of common carp as the response variable and independent variables from each disturbance pathway. Independent variables were selected and grouped according to other common carp studies (for a review, see Weber and Brown 2009). Some variables are included in multiple models (e.g. submersed macrophytes) but describe different pathways or mechanisms involved. For example, adult biotic foraging for benthic macroinvertebrates may uproot submersed aquatic vegetation, whereas adult abiotic foraging may mobilise sediment and reduce light attenuation for plant growth. Therefore, both the adult biotic foraging pathway and the adult abiotic foraging pathway result in reduced submersed macrophyte density, but the underlying mechanism (or pathway) is different. The greatest level of support is then given to the pathway with the largest global or cumulative effect of each variable in the model (evaluated by differences in AIC corrected for small sample bias, $\Delta \mathrm{AIC}_{\mathrm{c}}$, scores and model weights). Including each variable within a series of potential pathways would reveal bottom-up- or top-down-driven common carp effects and place them in a middle-out framework.

\section{Renovation approach \\ Renovation design}

A before-after-control-impact (BACI; McDonald et al. 2000) design was used over a period of 6 years (2005-10) to examine changes in the abiotic components and biotic community before ( $n=3$ years) and after $(n=3$ years) a fish toxicant (rotenone) was applied to Pony Lake to eradicate the fish community. Four randomly chosen sites were sampled seasonally (i.e. April, spring; July, summer; late September-early October, autumn) within both the treatment and reference (West Long) lake. The BACI design allowed inferences to be made on whether any changes in the treatment lake (Pony Lake) were caused by our treatment or some widespread environmental factor that may affect both lakes (e.g. precipitation, wind, temperature, hydrology).

An attempt was made to eradicate the entire carp-dominated Pony Lake fish community during October 2007 (end of Year 3 and after the autumn 2007 samples were collected) with a rotenone treatment. Rotenone was chosen as the most effective method to eradicate the common carp population (Weier and Starr 1950; Schrage and Downing 2004; Hicks and Ling 2015) 
and is an approved fish toxicant for fisheries management in the US by the US Environmental Protection Agency (Finlayson et al. 2010). It degrades quickly in the environment through hydrolytic, photolytic and biological processes, and residues are typically undetectable after several days, depending on abiotic and biotic conditions (Finlayson et al. 2001). Invertebrate communities have been reported to rebound quickly through recolonisation and regeneration (Beal and Anderson 1993), especially in prairie lakes (Melaas et al. 2001).

Liquid rotenone $(1855 \mathrm{~L})$ was applied through liquid sprayers mounted just above the lake surface from airboats, and powdered rotenone $(222 \mathrm{~kg})$ was delivered to the propeller wash of an outboard motor boat to mix the powder in the lake. An amphibious vehicle equipped with a plant sprayer was also used to apply the liquid in hard-to-access vegetated areas. A target rate of $3 \mathrm{ppm}$ was administered using both powder and liquid formulations. Following the renovation (i.e. restoring the lake back to a desired state), 504 largemouth bass (mean total length $196 \mathrm{~mm}$, range $155-416 \mathrm{~mm}$ ) and 52 bluegill (mean total length $189 \mathrm{~mm}$, range $112-229 \mathrm{~mm}$ ) were stocked from a nearby sandhill lake during June of 2009 (1 year after renovation). The fish stocking and addition of a piscivore to Pony Lake (treatment lake) enabled the fish community to more closely resemble that of West Long Lake (reference lake).

\section{Bottom-up and top-down effects sampling}

Total phosphorous, Secchi disc transparency and chlorophyll- $a$ were measured at four random locations at both the treatment and reference lake. Two samples of unfiltered lake water were collected at each site and frozen for later determination of total phosphorous following the methods of Wetzel and Likens (2000). Chlorophyll- $a$ was sampled from duplicate water samples using the same protocol described by Kaemingk et al. (2014). Submersed vegetation coverage was quantified during the summer (i.e. July; during peak foliage) using the methods described previously for the observational component (Paukert et al. 2002a). Benthic macroinvertebrates and zooplankton samples were collected, processed and converted to biomass $\left(\mu \mathrm{g} \mathrm{L}^{-1}\right)$ from two replicates at each of four offshore sites following methods outlined in Kaemingk et al. (2014). Less common taxa were excluded from further analyses because of the number of very small or zero abundances found within each lake.

\section{Fish sampling}

Twelve randomly chosen shoreline transects (100 m each) were walked within 3 days of the Pony Lake rotenone renovation in October 2007 and all dead fish were identified, counted and a subsample $(n=150)$ measured (total length (TL); mm). The mean number per transect was extrapolated to the entire shoreline to obtain population estimates. The mean weight of each species was based on length and estimated using speciesspecific standard weight equations (Murphy et al. 1991) and then extrapolated (multiplied by) to the population estimate to obtain the estimated population biomass. Pony Lake was then sampled each year after renovation (i.e. 2008-10) for fish during early June (trap nets and cloverleaf traps for age-0 fish, 2008, 2009, 2010; electrofished entire shoreline, 2009, 2010). Each three-lobed cloverleaf trap was constructed of galvanised $6.4-\mathrm{mm}$ bar mesh, with three $12.7-\mathrm{mm}$ wide openings between lobes to accommodate the entrance of small fish (Kaemingk and Willis 2012). The fish community was also sampled in West Long Lake during 2006, 2008 and 2010 with experimental gill nets (August), night-time electrofishing and trap nets (May) each year (Wanner 2011).

\section{Statistical analysis}

We used repeated generalised linear mixed models (PROC MIXED; SAS, ver. 9.3; SAS Institute; McDonald et al. 2000) to determine whether bottom-up effects (i.e. total phosphorus, Secchi disc transparency, submersed vegetation and chlorophyll-a) or top-down effects (i.e. zooplankton and benthic macroinvertebrates) had occurred in the treatment lake. Data were normalised by performing $\log _{10}(n+1),(n+2)^{-1}$ and $\sqrt{(n+1)}$ transformations to account for the zeros encountered. Macroinvertebrate density and biomass, zooplankton density and biomass, and physiochemical data, which were not normally distributed, were analysed using a quasi-likelihood generalised linear model method (PROC GLIMMIX; SAS ver. 9.3; SAS Institute; McDonald et al. 2000). Both linear models allowed for fixed and random effects. The model included fixed treatment (TR), period (B; before or after renovation), seasons nested within periods $(S(B))$ as an additive factor stabilising variation among the three seasons sampled (i.e. spring, summer and autumn; Louhi et al. 2011) and a treatment by period interaction effect $(\mathrm{TR} \times \mathrm{B})$. Sampling sites were nested within treatment and included as random effects, and season was nested in each year sampled to control for experimental error on repeated measurements through time (McDonald et al. 2000; Pabian and Brittingham 2007). We documented the treatment by time period interaction to evaluate the effects of the renovation in Pony Lake. Following a significant interaction, two contrasts were performed to examine whether least square means differed before and after the treatment in Pony Lake, West Long Lake or both lakes (SAS ver. 9.3; SAS Institute). Vegetation coverage was analysed using a repeated-measures ANOVA (i.e. time as the repeated measure) and the maximum likelihood method (Littell et al. 1998).

Least square means were calculated using ANOVA for all significant treatment by time effect variables (except for vegetation coverage) identified in the previous analysis to examine which year after renovation (i.e. Year 1, 2 or 3 ) the effect occurred (Glasby and Underwood 1996). Seasonal means were treated as the experimental unit where the 3 years before the renovation were compared to Years 1, 2 and 3 after renovation separately for the treatment lake (Pabian and Brittingham 2007). Differences were assessed at $\alpha \leq 0.05$ to guard against a Type I error due to the experimental treatment and nature of this portion of the study (Mapstone 1995).

\section{Results}

\section{Observational}

\section{Bottom-up effects}

Sandhill lakes without common carp had over double mean Secchi depth $\left(F_{1,14}=7.31, P=0.02\right)$ and triple the submersed 

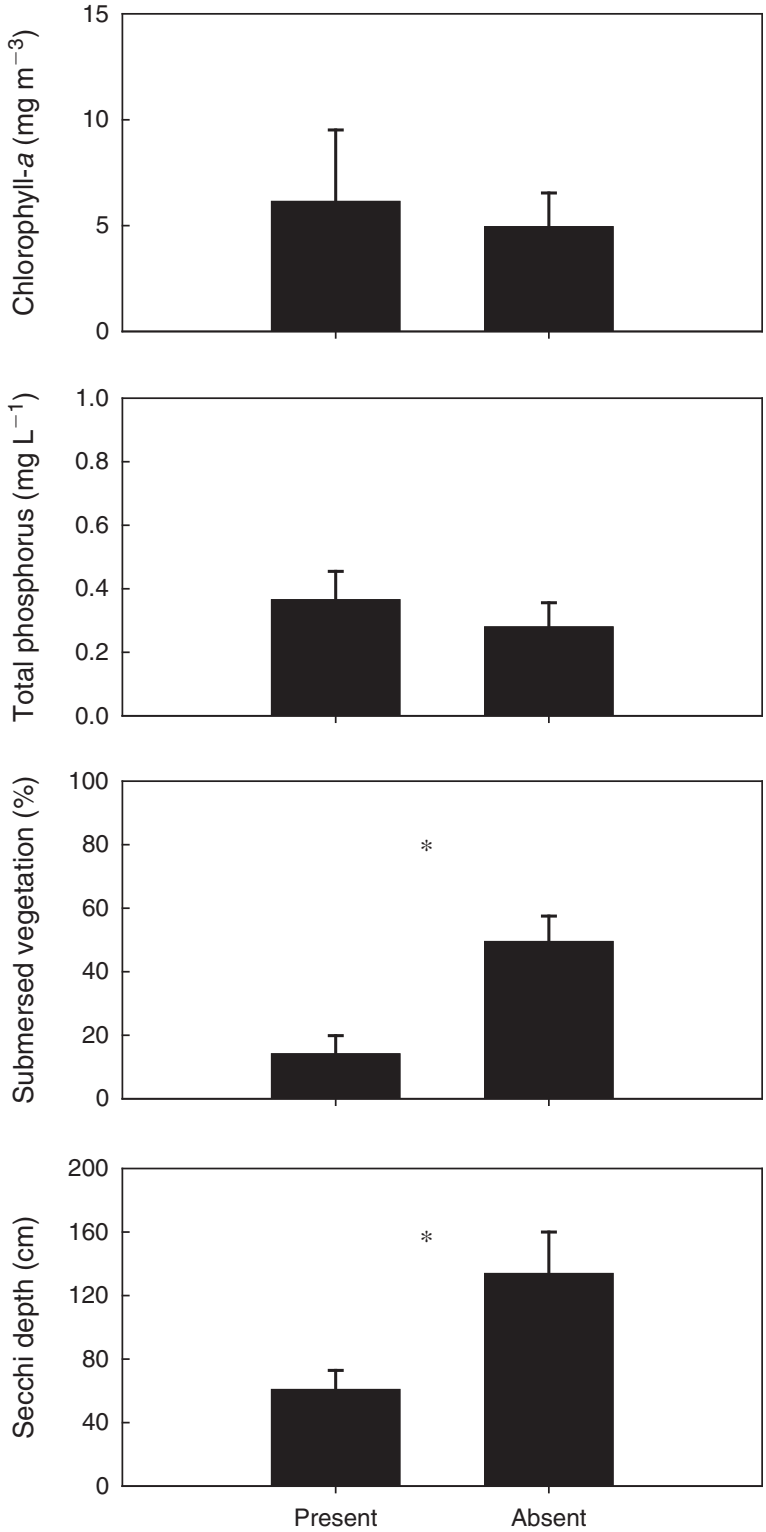

Fig. 2. Mean ( \pm s.e.) values of Secchi depth, submersed vegetation lake coverage, total phosphorus and chlorophyll- $a$ in eight lakes with common carp present and eight lakes with common carp absent during 1998 and 1999. Asterisks indicate significant differences at $\alpha \leq 0.10$ from a one-way ANOVA.

vegetation coverage compared with lakes with common carp ( $F_{1,14}=14.41, P<0.01$; Fig. 2$)$. However, total phosphorous $\left(F_{1,14}=0.63, \quad P=0.44\right)$ and chlorophyll- $a \quad\left(F_{1,14}=0.63\right.$, $P=0.44)$ levels did not differ between lakes with or without common carp (Fig. 2).

\section{Top-down effects}

Lakes with common carp had higher densities $\left(F_{1,14}=7.11\right.$, $P=0.02)$ and biomass $\left(F_{1,14}=8.46, P=0.01\right)$ of cladoceran zooplankton (Fig. 3). Copepod densities $\left(F_{1,14}=1.49, P=0.24\right)$ and biomass $\left(F_{1,14}=1.88, P=0.19\right)$ were similar between lakes with and without common carp (Fig. 3). In addition, no significant differences were detected between lakes with and without common carp relating to total benthic macroinvertebrate densities $\left(F_{1,14}=0.41, P=0.53\right)$ because of the wide range of macroinvertebrate densities in lakes without common carp.

Bluegill recruitment, growth and mortality were similar across lakes with and without common carp (recruitment $F_{1,9}=0.68, P=0.43$; growth $F_{1,8}=0.01, P=0.94$; mortality $F_{1,6}=0.32, P=0.59$; Fig. 4$)$. In contrast, yellow perch mortality was greater in lakes with common carp present $\left(F_{1,9}=3.84\right.$, $P=0.08)$ and recruitment variability was higher in lakes without common carp $\left(F_{1,10}=3.28, P=0.10\right.$; Fig. 4). The top predator, largemouth bass, experienced lower mortality rates $\left(F_{1,7}=7.19, P=0.03\right)$ and faster growth rates $\left(F_{1,7}=7.09\right.$, $P=0.03$ ) in lakes containing common carp (Fig. 4). However, yellow perch growth $\left(F_{1,10}=0.27, P=0.61\right)$ and largemouth bass recruitment $\left(F_{1,8}=0.78, P=0.40\right)$ did not differ between treatments (Fig. 4).

\section{Middle-out effects}

The common carp adult abiotic pathway was the most supported model (i.e. lowest AIC corrected for small sample bias, $\mathrm{AIC}_{\mathrm{c}}$, and highest model weight) compared with the early life feeding, adult biotic and adult nutrient pathway models (Table 1). The adult abiotic pathway included water transparency, submersed macrophytes and zooplankton variables. The next supported model (model weight $=0.23$ ) was the early life feeding pathway, which also included phytoplankton as an additional variable (but minus submersed macrophytes) to that of the abiotic pathway. However, the adult biotic and adult nutrient pathways should not be considered as the most probable middle-out response to common carp effects in these systems (model weights $=0$; Table 1; Fig. 1 ).

\section{Renovation \\ Fish sampling}

The Pony Lake fish community was dominated by adult common carp ( $76 \%$ of the total standing stock) at the time of the October 2007 renovation (Table 2). Post-treatment sampling revealed an incomplete fish community renovation. All species present at the time of the renovation were subsequently detected (in the following spring) but in lower abundances, except for common carp and yellow perch, which were not detected. Alternatively, no changes in the West Long Lake fish community were documented during the study (i.e. same species present).

\section{Bottom-up effects}

Secchi depth and submersed vegetation increased in the treatment lake after the renovation $(t=4.31, P<0.0001$ and $t=2.47, P=0.04$ respectively; Fig. 5). In contrast, Secchi depth decreased in the reference lake, but no change was observed in submersed vegetation $(t=-4.58, P<0.0001$ and $t=-1.05$, $P=0.32$ respectively). There was no treatment by time interaction effect for total phosphorous $\left(F_{1,104}=0.01, P=0.91\right)$. However, chlorophyll- $a$ in the treatment lake decreased after 



Fig. 3. Mean ( \pm s.e.) values of copepod and cladoceran zooplankton density and biomass in eight lakes with common carp present and eight lakes with common carp absent during 1998 and 1999. Asterisks indicate significant differences at $\alpha \leq 0.10$ from a one-way ANOVA.

the renovation $(t=-4.69, P<0.0001)$, but there was no difference in the reference lake ( $t=1.80, P=0.07$; Fig. 5).

\section{Top-down effects}

Cladoceran and copepod densities decreased in the treatment lake after the renovation $(t=-3.42, P<0.01$ and $t=-6.77$, $P<0.0001$ respectively), but no change was observed in the reference lake $(t=0.14, P=0.99$ and $t=0.59, P=0.94$ respectively). In contrast, cladoceran biomass increased substantially $(t=2.66, P=0.04)$, but copepod biomass decreased $(t=-4.84$, $P<0.0001)$, in the treatment lake after the renovation. No treatment effect was observed in the reference lake for either cladoceran or copepod biomass $(t=0.10, P=0.99$ and $t=0.86$, $P=0.82$ respectively; Fig. 6). Total benthic macroinvertebrate density and biomass were unaffected by the renovation in both the treatment $(t=2.04, P=0.18$ and $t=1.69, P=0.09$ respectively) and reference $\left(t=-0.37, P=0.98\right.$ and $t={ }_{0.11}, P=0.91$ respectively) lakes (Fig. 7).

\section{Timing}

Almost all variables deviated from pre-renovation levels in the treatment lake by Year 2 after renovation. Secchi depth, a measure of water clarity, was the first metric to respond in the treatment lake following the renovation (Fig. 5). An increase in water clarity was succeeded by a decrease in chlorophyll- $a$ and a decrease in both copepod density and biomass in Year 2 (Figs 5, 6). Only cladoceran density experienced a decline by Year 3, whereas no difference was identified for cladoceran biomass within each individual year after renovation, despite an overall significant increase.

\section{Discussion}

Common carp reduced water transparency and submersed vegetation density in both studies and caused an increase in phytoplankton (experimental study), altered copepod (experimental study) and cladoceran densities and biomass and affected the fish community. Consequently, middle-out effects were evident in both the observational and experimental studies (summarised in Table 3). It was useful to consider multiple disturbance pathway models (opposed to either top-down or bottom-up) that were generated or hypothesised from the existing literature (Fig. 1). Basic information concerning the life history or behavioural ecology of a species will be imperative to fully understand and identify intricate trophic linkages (Table 1). At least one metric from each trophic level was affected, but the magnitude of each effect differed across levels. A bidirectional effect was evident as both bottom-up and topdown processes were revealed. Placing species in a common functional feeding guild may mask food web effects using a traditional top-down or bottom-up framework (MacNeil et al. 1997). Therefore, species traits and autecology may allow for a more robust assessment of trophic linkages (Poff et al. 2006; Morales-Castilla et al. 2015). Without this specific knowledge of proximity, directionality and causation, it would be difficult to effectively direct and execute successful management or conservation efforts.

The trophic cascade pattern was clear (i.e. middle-out) but the process or pathway was more difficult to interpret. Considering the four major common carp disturbance pathway options (Fig. 1), adult abiotic foraging appeared to be strongest compared with the early life feeding, adult biotic or adult 

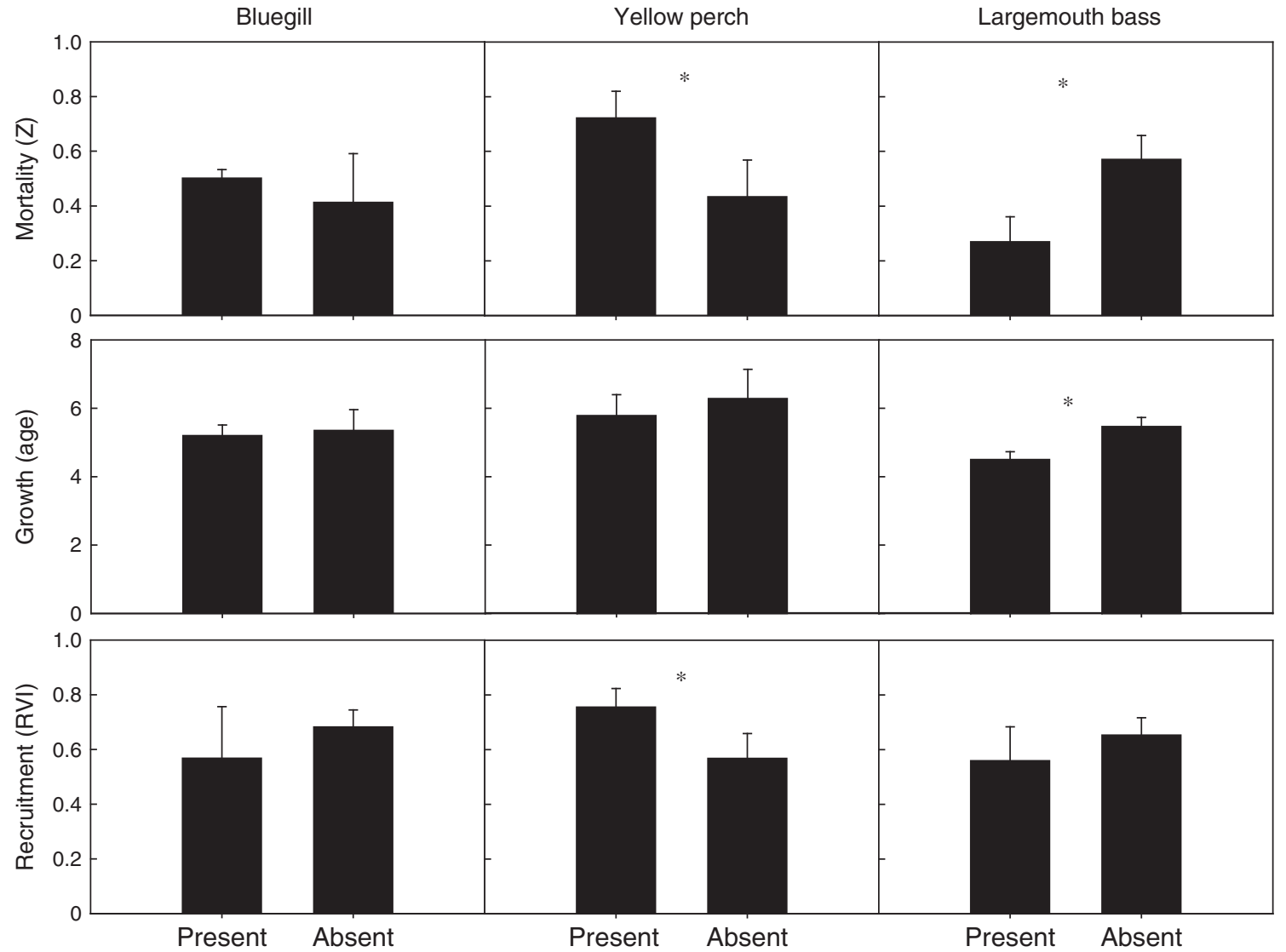

Fig. 4. Mean values ( \pm s.e.) of recruitment, growth and mortality for bluegill, yellow perch and largemouth bass in eight lakes with common carp present and eight lakes with common carp absent during 1998 and 1999. Growth describes the time (in years) for each species to reach preferred lengths (bluegill $200 \mathrm{~mm}$, yellow perch $250 \mathrm{~mm}$, largemouth bass $380 \mathrm{~mm}$; Gabelhouse 1984) and $Z$ represents total instantaneous mortality (Ricker 1975). The recruitment variability index (RVI) ranged from -1 to 1 , with increasing values indicating less recruitment variability (i.e. consistent; Guy and Willis 1995). Asterisks indicate significant differences at $\alpha \leq 0.10$ from a one-way ANOVA.

Table 1. Comparison of pathway models (and variables, listed consecutively according to impact proximity) examining middle-out effects of common carp (see Fig. 1)

Results include the number of parameters $(\mathrm{K})$, Akaike information criterion corrected for small sample bias $\left(\mathrm{AIC}_{\mathrm{c}}\right)$, differences in $\mathrm{AIC}_{\mathrm{c}}\left(\Delta \mathrm{AIC}_{\mathrm{c}}\right)$, evidence ratios $(\mathrm{ER})$ and weight of support for each model $\left(\mathrm{W}_{\mathrm{i}}\right)$

\begin{tabular}{|c|c|c|c|c|c|}
\hline Pathway model & $\mathrm{K}$ & $\mathrm{AIC}_{\mathrm{c}}$ & $\Delta \mathrm{AIC}_{\mathrm{c}}$ & ER & $\mathrm{W}_{\mathrm{i}}$ \\
\hline Adult abiotic (water clarity, submersed macrophytes, zooplankton) & 5 & 14.06 & 0.00 & 1.00 & 0.77 \\
\hline Early life feeding (zooplankton, phytoplankton, water clarity) & 5 & 16.44 & 2.38 & 0.30 & 0.23 \\
\hline Adult biotic (benthic macroinvertebrates, submersed macrophytes, water clarity) & 5 & 24.79 & 10.72 & 0.00 & 0.00 \\
\hline Adult nutrient (nutrients, phytoplankton, water clarity) & 5 & 27.25 & 13.19 & 0.00 & 0.00 \\
\hline
\end{tabular}

nutrient pathways. Water clarity was immediately affected during the first year after renovation and also reduced in the observational lakes with common carp present (see also Schrage and Downing 2004). This reduction in water clarity likely stemmed from the foraging behaviour of adult common carp and physical turbidity, and not by resuspending benthic nutrients (no effect in either study), which would have caused an increase in phytoplankton (Parkos et al. 2003). Physical turbidity can limit light penetration and submersed vegetation growth (Scheffer and Jeppesen 1998). The loss of submersed vegetation coverage observed in both studies may lead to many other deleterious ecosystem effects and even ecological stable state shifts (Scheffer et al. 1993), including the shifts in zooplankton community dynamics observed in the present study (van Donk and van de Bund 2002; Weber and Brown 2009). 
Table 2. Initial population density and biomass estimates for the fish community in Pony Lake, Nebraska, revealed during the October 2007 rotenone renovation

\begin{tabular}{|c|c|c|c|c|c|c|}
\hline Species & $\begin{array}{l}\text { Mean }( \pm \text { s.e. }) \text { number } \\
\text { per } m \text { shoreline }\end{array}$ & Total abundance & $\begin{array}{c}\text { Density } \\
\left(\text { number ha }^{-1}\right)\end{array}$ & $\begin{array}{c}\text { Mean } \\
\text { weight }(\mathrm{g})\end{array}$ & $\begin{array}{c}\text { Total } \\
\text { biomass }(\mathrm{kg})\end{array}$ & $\begin{array}{l}\text { Standing stock } \\
\qquad\left(\mathrm{kg} \mathrm{ha}^{-1}\right)\end{array}$ \\
\hline Black bullhead & $7.63 \pm 4.01$ & 25179 & 393.4 & 71 & 1796 & 28.1 \\
\hline Adult common carp & $1.64 \pm 0.44$ & 5412 & 84.6 & 2770 & 14990 & 234.2 \\
\hline Age- 0 common carp & $4.85 \pm 1.01$ & 16005 & 250.1 & 46 & 737 & 11.5 \\
\hline Grass pickerel & $0.06 \pm 0.03$ & 198 & 3.1 & 35 & 7 & 0.1 \\
\hline Green sunfish & $14.80 \pm 7.00$ & 48840 & 763.1 & 22 & 1094 & 17.1 \\
\hline Golden shiner & $2.13 \pm 0.32$ & 7029 & 109.8 & 17 & 121 & 1.9 \\
\hline Pumpkinseed & $0.04 \pm 0.03$ & 132 & 2.1 & 24 & 3 & 0.1 \\
\hline Yellow perch & $0.01 \pm 0.01$ & 33 & 0.5 & 132 & 4 & 0.1 \\
\hline Fathead minnow & $805.5 \pm 21.7$ & 2658249 & 41535.1 & 1 & 1914 & 29.9 \\
\hline Totals & - & 2761077 & 43141.8 & - & 20666 & 322.9 \\
\hline
\end{tabular}

There is far less consistency among studies accounting for common carp effects on zooplankton community composition and dynamics (Vilizzi et al. 2015). Typically, common carp cause a reduction in large-bodied zooplankton (Weber and Brown 2009), but we observed the opposite effect. Large-bodied zooplankton densities and biomass (except for biomass in the experimental study) increased as a result of common carp, including small-bodied zooplankton in the experimental study. This pattern could be explained, in part, by the size composition of common carp across lakes examined (Nieoczym and Kloskowski 2014). Smaller carp may preferentially feed on zooplankton compared with larger carp that consume mainly macroinvertebrates; these food habits may also change seasonally (Nieoczym and Kloskowski 2014). The present study did not account for the size or age structure of common carp, but identified that both age- 0 (small) and adult (large) common carp were present in the treatment lake. Therefore, future studies should examine the role of common carp size on zooplankton community dynamics across multiple spatial and temporal scales to further resolve these complexities.

We found limited evidence to support the remaining three disturbance pathways, despite their importance or relevance in other studies (Vilizzi et al. 2015). Common carp population attributes (e.g. size structure, biomass, recruitment dynamics) and inherent ecosystem properties (e.g. substrate type, trophic state, bathymetry) are likely to cause different common carp ecosystem responses. Our common carp biomass estimate $\left(\sim 245 \mathrm{~kg} \mathrm{ha}^{-1}\right)$ was either below or on the low end of the critical biomass threshold typically attributed to widespread ecosystem disturbances (ranging from 200 to $450 \mathrm{~kg} \mathrm{ha}^{-1}$; for reviews, see Weber and Brown 2009; Vilizzi et al. 2015). However, shallow lakes may be more sensitive to a reduction in submersed macrophytes, compared with deep lakes, causing the observed common carp effects in the present study (Jeppesen et al. 1997). Moreover, invertebrate densities are much higher in these lakes compared with other surrounding ecosystems, and these invertebrate abundances do not appear to be strongly affected by fish predation (Paukert and Willis 2003). Therefore, common carp biomass densities may have been below a level necessary to directly reduce invertebrate densities by predation, ultimately limiting support for the early life feeding and adult biotic pathways. In addition, Nebraska sandhill lakes do not experience much external nutrient loading compared with water bodies with common carp in intensive agriculturally dominated systems (Jackson et al. 2010). This may explain why evidence was lacking for the adult nutrient pathway.

It appears trophic levels furthest away from direct impact may still be affected within a middle-out framework, but were weaker or less consistent compared with lower trophic levels. Less than half the fish species trait combinations examined were significant. We hypothesised that bluegill and not piscivores would be most affected, considering bluegill are an insectivore and closer in proximity to common carp-mediated effects (Egertson and Downing 2004; Wolfe et al. 2009). However, bluegill growth, recruitment, and mortality did not differ between lakes with and without common carp, but both piscivores (yellow perch and largemouth bass) exhibited differences between lakes. Fewer studies have examined common carp effects on fish species (highlighted in Weber and Brown 2009). Of these studies, most identified a decline in one or more dynamic rate functions (recruitment, growth, mortality; Egertson and Downing 2004; Wolfe et al. 2009). Mesocosm studies have documented common carp effects for young centrarchid life stages but not at the adult life stage. Although not directly comparable, largemouth bass recruitment and mortality patterns were similar, whereas growth rate effects in the present study were different compared with these previous mesocosm studies (Wolfe et al. 2009; Wahl et al. 2011). In contrast, we did not identify bluegill population differences between lakes with or without common carp (Wolfe et al. 2009; Wahl et al. 2011). Effects on largemouth bass could be more long lasting across life stages (i.e. carry-over effects; Harrison et al. 2011) compared with bluegill effects that are evident during the early life history but synergistically decouple as they reach adulthood. To our knowledge, no one has identified common carp effects on yellow perch populations by examining recruitment, growth and mortality. Age- 0 yellow perch mortality and recruitment was regulated by zooplankton availability in one of the lakes used for the observational study (Pelican Lake; Kaemingk et al. 2014). Thus, because common carp substantially modified zooplankton dynamics and composition, it could explain, in part, the increased mortality and recruitment variability of yellow perch in lakes with common carp. Predator-prey dynamics could also explain the higher mortality of yellow perch 

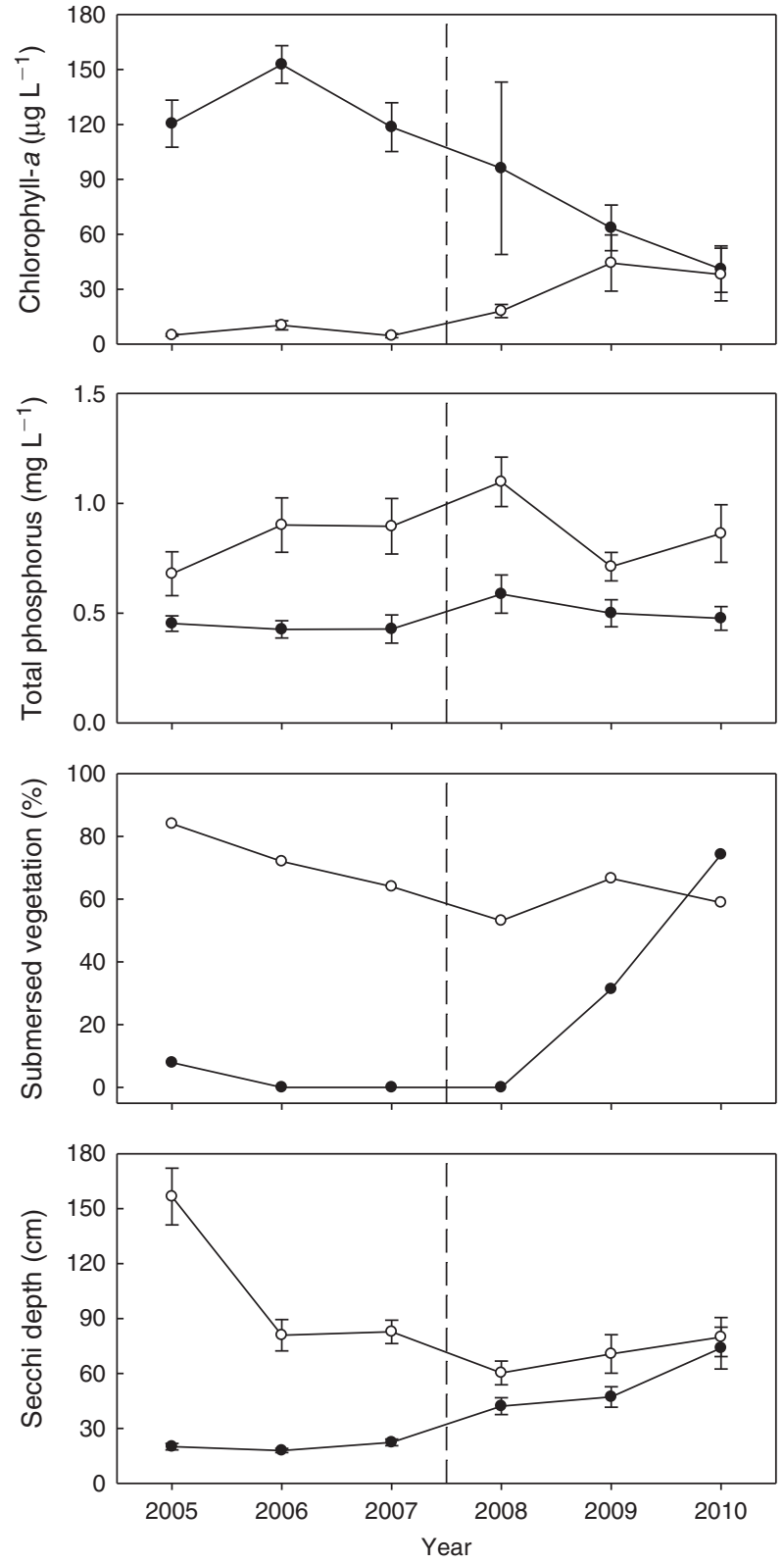

Fig. 5. Mean ( \pm s.e. $)$ values of Secchi depth, submersed vegetation lake coverage, total phosphorus and chlorophyll- $a$ over the period 2005-10 in the treatment (Pony, closed circles) and reference (West Long, open circles) lakes before and after (denoted by the vertical dashed line) common carp were removed from the treatment lake.

in lakes with common carp. Largemouth bass experienced lower mortality in lakes with common carp, which subsequently may lead to higher largemouth bass predation rates on yellow perch in these systems (Paukert et al. 2002b). It is clear that indirect effects channelled through a middle-out process may still affect (but to a lesser degree) trophic levels whose trophic position and distance could have provided a buffer from direct impact (i.e. compartments or subwebs; Krause et al. 2003).

The effect on and response time of each trophic level also varied in the experimental study. Most variables quickly responded ( $<2$ years) after common carp were removed from the treatment lake, despite other studies highlighting a slow regimen shift after a disturbance (Meijer et al. 1999; Gulati and van Donk 2002). By Year 3, all significantly modified variables (except cladoceran density) had completely shifted, including submersed macrophytes. Submersed macrophytes appear to be a critical component in shallow lake ecology and are negatively affected by common carp (Miller and Crowl 2006); macrophytes provide sediment stability, nutrient uptake, zooplankton predation refuge and increased grazing opportunities (Kufel and Ozimek 1994; Barko and James 1998). Thus, the removal of common carp allowed the lake to shift from a turbid water and limited submersed macrophyte state to a clear water and high density submersed macrophyte state. The ability to identify potential trophic interactions (e.g. pathways) and incorporating functional traits of specific species (e.g. common carp) in the community could offer the best strategy to address ecosystem-level management problems. Depending on the dominant trophic pathway and inherent ecosystem attributes, these lag effects could be shortened or lengthened but should be considered when assessing trophic ecology dynamics.

Overall, patterns and results were generally similar between observational and experimental studies despite the different approaches and limitations. The experimental portion included only one treatment and one reference lake, therefore preventing large-scale inferences to be made. We also attempted to create a similar fish assemblage between lakes by introducing a top-level piscivore (i.e. largemouth bass) to the treatment lake. It was unclear how effective this strategy was other than the results conformed to a middle-out process (Vilizzi et al. 2015), aligning more closely with the hypothesised common carp effects compared with a simple top-down predator effect (McQueen et al. 1986). Although the evaluation period in the present study exceeded that of many previous studies, it was likely shorter than what is required to effectively document some ecosystemlevel changes (Peterson 1984), such as generation times for fish (see Capon et. al 2015). Therefore, caution should be exercised when interpreting and applying these results to other ecosystems (Mac Nally et al. 2014; Capon et al. 2015). However, our findings reinforce previous work conducted on smaller spatiotemporal scales providing promise of broader utility despite these limitations (Vilizzi et al. 2015).

The results of the present study support the middle-out effects trophic cascade concept and further identify the need to include species trait information. Single species studies or understanding the interactions of one keystone species within a community has received criticism (Simberloff 1998). Excluding species trait information (or, in some cases, where information is lacking) could have major implications on the interpretation and understanding of food web ecology and trophic cascades. For example, predicting the direction and strength of food web effects could be greatly enhanced by incorporating habitat use, foraging behaviour and other dynamic predator-prey relationships (Schmitz et al. 2004). Moving towards incorporating species traits and organismal performance metrics could address inadequacies and disconnects between empirical studies and ecological food web modelling (van Veen and Sanders 2013). In the present study, known common carp foraging behaviour greatly improved the 

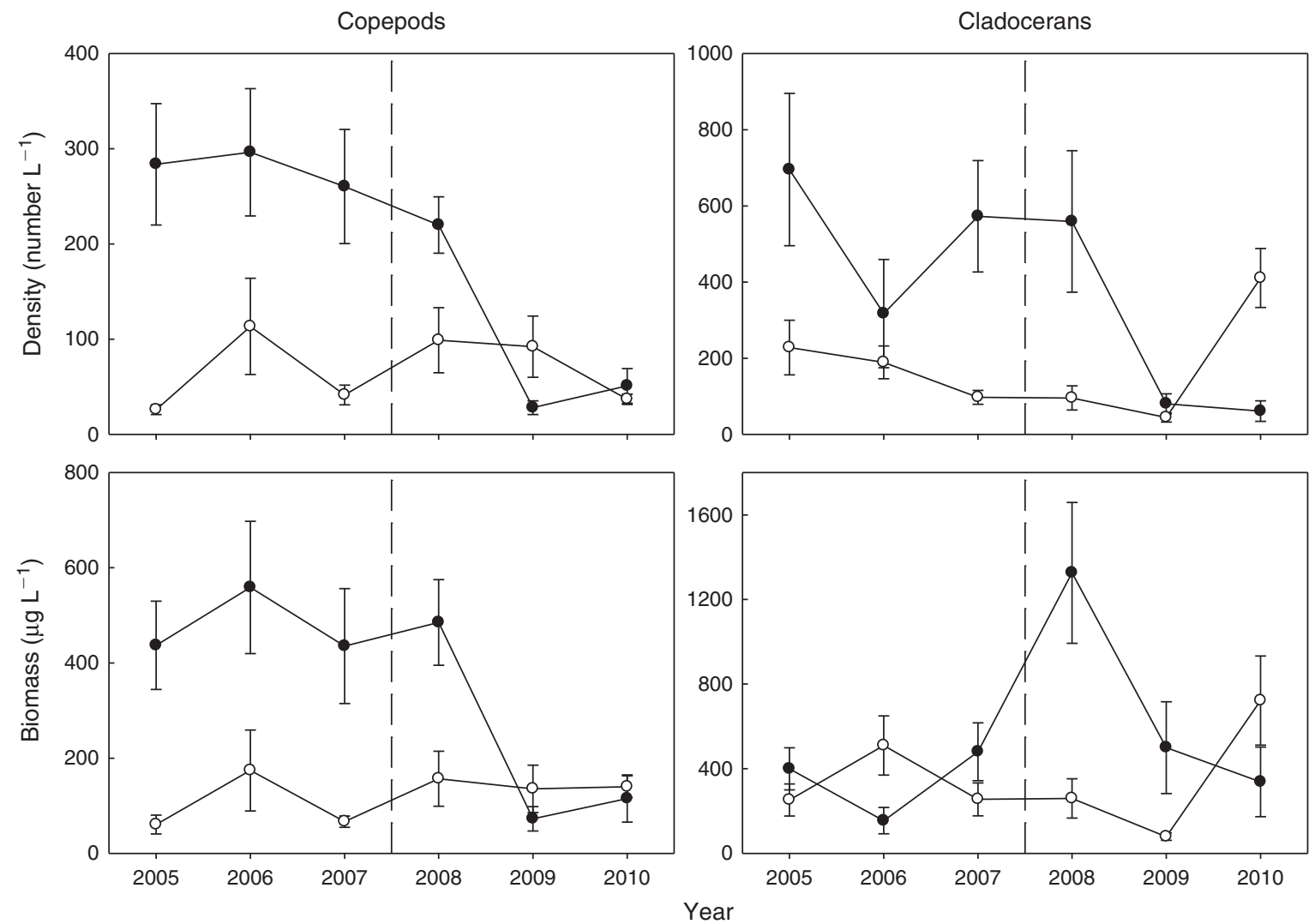

Fig. 6. Mean ( \pm s.e.) values of copepod and cladoceran zooplankton density and biomass over the period 2005-10 in the treatment (Pony, closed circles) and reference (West Long, open circles) lakes before and after (denoted by the vertical dashed line) common carp were removed from the treatment lake.
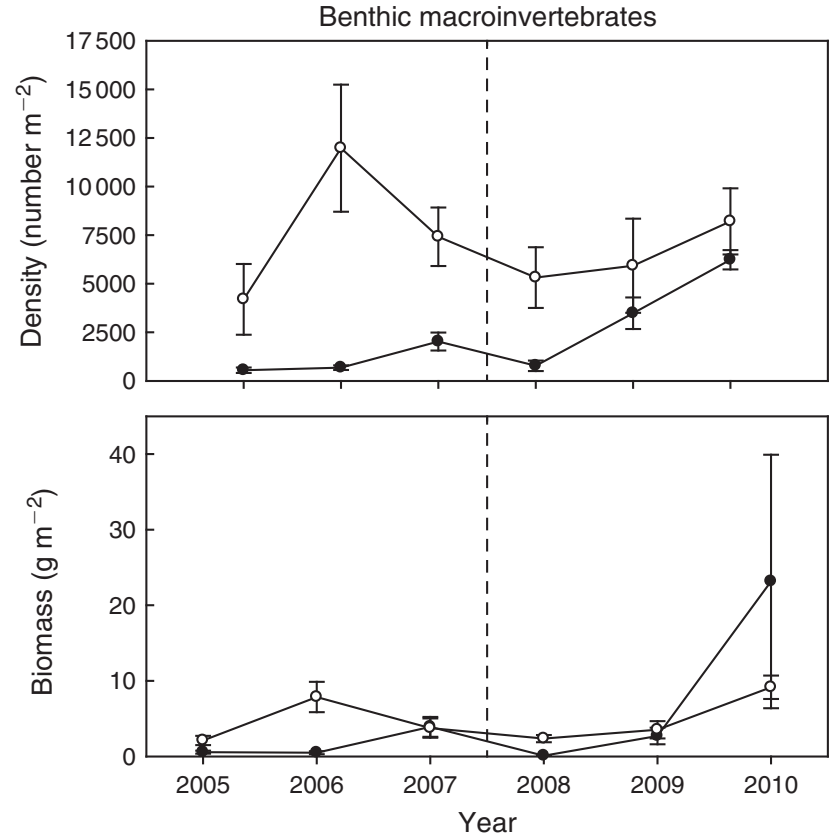

Fig. 7. Mean ( \pm s.e.) values of total benthic macroinvertebrate density and biomass over the period 2005-10 in the treatment (Pony, closed circles) and reference (West Long, open circles) lakes before and after (denoted by the vertical dashed line) common carp were removed from the treatment lake.
Table 3. Summary of bottom-up and top-down trophic effects caused by common carp in both observational and experimental studies

Each effect (i.e. 'yes') is followed by a sign (positive sign indicates an increase; negative sign indicates a decrease) corresponding to directional effects of common carp within each study. NA, not applicable

\begin{tabular}{|c|c|c|}
\hline Metric & Observational & Experimental \\
\hline \multicolumn{3}{|l|}{ Bottom-up } \\
\hline $\begin{array}{l}\text { Water } \\
\text { transparency }\end{array}$ & Yes $(-)$ & Yes $(-)$ \\
\hline $\begin{array}{l}\text { Submersed } \\
\text { vegetation }\end{array}$ & Yes $(-)$ & Yes $(-)$ \\
\hline Nutrients & No & No \\
\hline Phytoplankton & No & Yes $(+)$ \\
\hline \multicolumn{3}{|l|}{ Top-down } \\
\hline Copepod densities & No & Yes $(+)$ \\
\hline Copepod biomass & No & Yes (+) \\
\hline Cladoceran densities & Yes $(+)$ & Yes $(-)$ \\
\hline Cladoceran biomass & Yes $(+)$ & Yes $(+)$ \\
\hline $\begin{array}{l}\text { Benthic } \\
\text { macroinvertebrates }\end{array}$ & No & No \\
\hline \multicolumn{3}{|l|}{ Fish } \\
\hline Insectivore & No & NA \\
\hline $\begin{array}{l}\text { Lower-level } \\
\text { piscivore }\end{array}$ & $\begin{array}{l}\text { Yes } \\
\text { (mortality }+ \text {, recruitment }- \text { ) }\end{array}$ & NA \\
\hline $\begin{array}{l}\text { Upper-level } \\
\text { piscivore }\end{array}$ & $\begin{array}{l}\text { Yes } \\
\text { (mortality }-, \text { growth }+ \text { ) }\end{array}$ & NA \\
\hline
\end{tabular}


detection, interpretation and understanding of middle-out effects that would otherwise be difficult to achieve (MoralesCastilla et al. 2015).

\section{Acknowledgements}

The authors thank all technicians and personnel for field and laboratory assistance. J. Klammer, A. Hanson, A. Glidden, D. Hartman, J. Ryschon, D. Tunik, D. Graham and D. Krueger (Nebraska Game and Parks Commission) provided invaluable assistance. Thanks to M. Nenneman and the Valentine National Wildlife Refuge for providing facilities and graciously allowing access to refuge lakes. D. Shuman, W. Stancill and R. Klumb (United States Fish and Wildlife Service) provided assistance in obtaining fish samples and the authors gratefully acknowledge their efforts. B. Graeb provided insightful comments in the early stages of manuscript preparation and K. Pope also assisted at the later stages. Study funding was provided by Nebraska Game and Parks Commission, Sport Fish Restoration Project Number F-118-R administered through South Dakota State University. The Missouri Cooperative Fish and Wildlife Research Unit is jointly sponsored by the Missouri Department of Conservation, the University of Missouri, the US Geological Survey, the US Fish and Wildlife Service, and the Wildlife Management Institute. The use of trade names or products does not constitute endorsement by the US Government.

\section{References}

Allen, J. I., and Fulton, E. A. (2010). Top-down, bottom-up or middle-out? Avoiding extraneous detail and over-generality in marine ecosystem models. Progress in Oceanography 84, 129-133. doi:10.1016/ J.POCEAN.2009.09.016

Bajer, P. G., and Sorensen, P. W. (2012). Using boat electrofishing to estimate the abundance of invasive common carp in small Midwestern lakes. North American Journal of Fisheries Management 32, 817-822. doi:10.1080/02755947.2012.690822

Barko, J. W., and James, W. F. (1998). Effects of submerged aquatic macrophytes on nutrient dynamics, sedimentation, and resuspension. In 'The Structuring Role of Submerged Macrophytes in Lakes'. (Eds E. Jeppesen, M. Sondergaard, M. Sondergaard, and K. Christofferson.) pp. 197-214. (Springer: New York.)

Beal, D. L., and Anderson, R. V. (1993). Response of zooplankton to rotenone in a small pond. Bulletin of Environmental Contamination and Toxicology 51, 551-556. doi:10.1007/BF00192171

Borer, E. T., Seabloom, E. W., Shurin, J. B., Anderson, K. E., Blanchette, C. A., Broitman, B., Cooper, S. D., and Halpern, B. S. (2005). What determines the strength of a trophic cascade? Ecology 86, 528-537. doi:10.1890/03-0816

Burnham, K. P., and Anderson, D. R. (2002). 'Model Selection and MultiModel Inference: A Practical Information-Theoretic Approach.' (Springer: New York.)

Capon, S. J., Lynch, A. J. J., Bond, N., Chessman, B. C., Davis, J., Davidson, N., Finlayson, M., Gell, P. A., Hohnberg, D., Humphrey, C., and Kingsford, R. T. (2015). Regime shifts, thresholds and multiple stable states in freshwater ecosystems; a critical appraisal of the evidence. The Science of the Total Environment 534, 122-130. doi:10.1016/J.SCITOTENV.2015.02.045

Carpenter, S. R., and Kitchell, J. F. (1988). Consumer control of lake productivity. Bioscience 38, 764-769. doi:10.2307/1310785

Carpenter, S. R., Kitchell, J. F., and Hodgson, J. R. (1985). Cascading trophic interactions and lake productivity. Bioscience 35, 634-639. doi:10.2307/ 1309989

Culver, D. A., Boucherle, M. M., Bean, D. J., and Fletcher, J. W. (1985). Biomass of freshwater crustacean zooplankton from length-weight regressions. Canadian Journal of Fisheries and Aquatic Sciences $\mathbf{4 2}$, 1380-1390. doi:10.1139/F85-173
Cummins, K. W., and Wuycheck, J. C. (1971). 'Caloric Equivalents for Investigations in Ecological Energetics.' (Schweizerbart: Stuttgart, Germany.)

de Bello, F., Lavorel, S., Díaz, S., Harrington, R., Cornelissen, J. H., Bardgett, R. D., Berg, M. P., Cipriotti, P., Feld, C. K., and Hering, D. (2010). Towards an assessment of multiple ecosystem processes and services via functional traits. Biodiversity and Conservation 19, 2873-2893. doi:10.1007/S10531-010-9850-9

DeAngelis, D. L. (2013). Intraspecific trait variation and its effects on food chains. Mathematical Biosciences 244, 91-97. doi:10.1016/J.MBS. 2013.04.008

DeVries, D. R., and Stein, R. A. (1992). Complex interactions between fish and zooplankton: quantifying the role of an open-water planktivore. Canadian Journal of Fisheries and Aquatic Sciences 49, 1216-1227. doi:10.1139/F92-137

Díaz, S., and Cabido, M. (2001). Vive la difference: plant functional diversity matters to ecosystem processes. Trends in Ecology \& Evolution 16, 646-655. doi:10.1016/S0169-5347(01)02283-2

Duffy, J. E., Cardinale, B. J., France, K. E., McIntyre, P. B., Thébault, E., and Loreau, M. (2007). The functional role of biodiversity in ecosystems: incorporating trophic complexity. Ecology Letters 10, 522-538. doi:10.1111/J.1461-0248.2007.01037.X

Dumont, H. J., Velde, I., and Dumont, S. (1975). The dry weight estimate of biomass in a selection of Cladocera, Copepoda and Rotifera from the plankton, periphyton and benthos of continental waters. Oecologia 19, 75-97. doi:10.1007/BF00377592

Egertson, C. J., and Downing, J. A. (2004). Relationship of fish catch and composition to water quality in a suite of agriculturally eutrophic lakes. Canadian Journal of Fisheries and Aquatic Sciences 61, 1784-1796. doi:10.1139/F04-109

Finlayson, B. J., Siepmann, S., and Trumbo, J. (2001). Chemical residues in surface and ground waters following rotenone applicaiton to California lakes and streams. In 'Rotenone in Fisheries: Are the Rewards Worth the Risks?' (Eds R. L. Cailteux, L. DeMong, B. J. Finlayson, W. Horton, W. McClay, R. A. Schnick, and C. Thompson.) pp. 37-53. (American Fisheries Society: Bethesda, MD, USA.)

Finlayson, B. J., Schnick, R., Skaar, D., Anderson, J., Demong, L., Duffield, D., Horton, W., and Steinkjer, J. (2010). 'Planning and Standard Operating Procedures for the Use of rotenone in Fish Management: Rotenone SOP Manual.' (American Fisheries Society: Bethesda, MD.)

Gabelhouse, D. W. Jr (1984). A length-categorization system to assess fish stocks. North American Journal of Fisheries Management 4, 273-285. doi:10.1577/1548-8659(1984)4<273:ALSTAF > 2.0.CO;2

Glasby, T. M., and Underwood, A. J. (1996). Sampling to differentiate between pulse and press perturbations. Environmental Monitoring and Assessment 42, 241-252. doi:10.1007/BF00414371

Greeney, H. F., Meneses, M. R., Hamilton, C. E., Lichter-Marck, E., Mannan, R. W., Snyder, N., Snyder, H., Wethington, S. M., and Dyer, L. A. (2015). Trait-mediated trophic cascade creates enemy-free space for nesting hummingbirds. Science Advances 1, e1500310. doi:10.1126/ SCIADV.1500310

Gulati, R. D., and van Donk, E. (2002). Lakes in the Netherlands, their origin, eutrophication and restoration: state-of-the-art review. Hydrobiologia 478, 73-106. doi:10.1023/A:1021092427559

Guy, C. S., and Willis, D. W. (1995). Population characteristics of black crappies in South Dakota waters: a case for ecosystem-specific management. North American Journal of Fisheries Management 15, 754-765. doi:10.1577/1548-8675(1995)015<0754:PCOBCI > 2.3.CO;2

Harrison, X. A., Blount, J. D., Inger, R., Norris, D. R., and Bearhop, S. (2011). Carry-over effects as drivers of fitness differences in animals. Journal of Animal Ecology 80, 4-18. doi:10.1111/J.1365-2656.2010.01740.X

Hicks, B. J., and Ling, N. (2015) Carp as an invasive species. In 'Biology and Ecology of Carp'. (Eds C. Pietsch and P. E. Hirsch.) pp. 244-281. (CRC Press.) 
Jackson, Z. J., Quist, M. C., Downing, J. A., and Larscheid, J. G. (2010). Common carp (Cyprinus carpio), sport fishes, and water quality: ecological thresholds in agriculturally eutrophic lakes. Lake and Reservoir Management 26, 14-22. doi:10.1080/07438140903500586

Jeppesen, E., Peder Jensen, J., Søndergaard, M., Lauridsen, T., Junge Pedersen, L., and Jensen, L. (1997). Top-down control in freshwater lakes: the role of nutrient state, submerged macrophytes and water depth. In 'Shallow Lakes '95: Trophic Cascades in Shallow Freshwater and Brackish Lakes (Developments in Hydrobiology)', Vol. 119. (Eds L. Kufel, A. Prejs, and J. Rybak.) pp. 151-164. (Springer.) doi:10.1023/A:1017046130329

Jolley, J. C., Willis, D. W., Debates, T. J., and Graham, D. D. (2008). The effects of mechanically reducing northern pike density on the sport fish community of West Long Lake, Nebraska, USA. Fisheries Management and Ecology 15, 251-258. doi:10.1111/J.1365-2400.2008.00609.X

Jones, C. G., Lawton, J. H., and Shachak, M. (1994). Organisms as ecosystem engineers. Oikos 69, 373-386. doi:10.2307/3545850

Kaemingk, M., and Willis, D. (2012). Mensurative approach to examine potential interactions between age-0 yellow perch (Perca flavescens) and bluegill (Lepomis macrochirus). Aquatic Ecology 46, 353-362. doi:10.1007/S10452-012-9406-Z

Kaemingk, M. A., and Willis, D. W. (2014). Abiotic and biotic influences on fish communities in Nebraska Sandhill lakes. Nebraska Game and Parks Commission, Federal Aid in Sport Fish Restoration, Project Number F-118-R, Study III, Completion Report, Lincoln.

Kaemingk, M. A., Graeb, B. D. S., and Willis, D. W. (2014). Temperature, hatch date, and prey availability influence age- 0 yellow perch growth and survival. Transactions of the American Fisheries Society $\mathbf{1 4 3}$ 845-855. doi:10.1080/00028487.2014.886622

Krause, A. E., Frank, K. A., Mason, D. M., Ulanowicz, R. E., and Taylor, W. W. (2003). Compartments revealed in food-web structure. Nature 426, 282-285. doi:10.1038/NATURE02115

Kufel, L., and Ozimek, T. (1994). Can Chara control phosphorus cycling in Lake Łuknajno (Poland)? Hydrobiologia 275-276, 277-283. doi:10.1007/ BF00026718

Lind, O. T. (1979). 'Handbook of Common Methods in Limnology.' 2nd edn. (C. V. Mosby Co.: St Louis, MO, USA.)

Littell, R. C., Henry, P. R., and Ammerman, C. B. (1998). Statistical analysis of repeated measures data using SAS procedures. Journal of Animal Science 76, 1216-1231.

Louhi, P., Mykrä, H., Paavola, R., Huusko, A., Vehanen, T., Mäki-Petäys, A., and Muotka, T. (2011). Twenty years of stream restoration in Finland: little response by benthic macroinvertebrate communities. Ecological Applications 21, 1950-1961. doi:10.1890/10-0591.1

Mac Nally, R., Albano, C., and Fleishman, E. (2014). A scrutiny of the evidence for pressure-induced state shifts in estuarine and nearshore ecosystems. Austral Ecology 39, 898-906. doi:10.1111/AEC.12162

MacNeil, C., Dick, J. T., and Elwood, R. W. (1997). The trophic ecology of freshwater Gammarus spp. (Crustacea: Amphipoda): problems and perspectives concerning the functional feeding group concept. Biological Reviews of the Cambridge Philosophical Society 72, 349-364. doi:10.1017/S0006323196005038

Mapstone, B. D. (1995). Scalable decision rules for environmental impact studies: effect size, type I, and type II errors. Ecological Applications $\mathbf{5}$ 401-410. doi:10.2307/1942031

Matsuzaki, S.-i., Usio, N., Takamura, N., and Washitani, I. (2009). Contrasting impacts of invasive engineers on freshwater ecosystems: an experiment and meta-analysis. Oecologia 158, 673-686. doi:10.1007/ S00442-008-1180-1

McCarraher, D. B. (1977). 'Nebraska’s Sandhills Lakes.' (Nebraska Game and Parks Commission: Lincoln, NE, USA.)

McDonald, T. L., Erickson, W. P., and McDonald, L. L. (2000). Analysis of count data from before-after control-impact studies. Journal of Agricultural Biological \& Environmental Statistics 5, 262-279. doi:10.2307/ 1400453
McQueen, D. J., Post, J. R., and Mills, E. L. (1986). Trophic relationships in freshwater pelagic ecosystems. Canadian Journal of Fisheries and Aquatic Sciences 43, 1571-1581. doi:10.1139/F86-195

Meijer, M.-L., de Boois, I., Scheffer, M., Portielje, R., and Hosper, H. (1999). Biomanipulation in shallow lakes in the Netherlands: an evaluation of 18 case studies. Hydrobiologia 408-409, 13-30. doi:10.1023/ A: 1017045518813

Melaas, C. L., Zimmer, K. D., Butler, M. G., and Hanson, M. A. (2001) Effects of rotenone on aquatic invertebrate communities in prairie wetlands. Hydrobiologia 459, 177-186. doi:10.1023/A:1012514124430

Miller, S. A., and Crowl, T. A. (2006). Effects of common carp (Cyprinus carpio) on macrophytes and invertebrate communities in a shallow lake. Freshwater Biology 51, 85-94. doi:10.1111/J.1365-2427.2005.01477.X

Morales-Castilla, I., Matias, M. G., Gravel, D., and Araújo, M. B. (2015) Inferring biotic interactions from proxies. Trends in Ecology \& Evolution 30, 347-356. doi:10.1016/J.TREE.2015.03.014

Murphy, B. R., Willis, D. W., and Springer, T. A. (1991). The relative weight index in fisheries management: status and needs. Fisheries (Bethesda, Md.) 16, 30-38. doi:10.1577/1548-8446(1991)016<0030:TRWIIF $>2.0$. CO;2

Nieoczym, M., and Kloskowski, J. (2014). The role of body size in the impact of common carp Cyprinus carpio on water quality, zooplankton, and macrobenthos in ponds. International Review of Hydrobiology 99 212-221. doi:10.1002/IROH.201301644

Noss, R. F. (1990). Indicators for monitoring biodiversity: a hierarchical approach. Conservation Biology 4, 355-364. doi:10.1111/J.1523-1739. 1990.TB00309.X

Pabian, S. E., and Brittingham, M. C. (2007). Terrestrial liming benefits birds in an acidified forest in the northeast. Ecological Applications 17, 2184-2194. doi:10.1890/07-0394.1

Pace, M. L., Cole, J. J., Carpenter, S. R., and Kitchell, J. F. (1999). Trophic cascades revealed in diverse ecosystems. Trends in Ecology \& Evolution 14, 483-488. doi:10.1016/S0169-5347(99)01723-1

Parkos, J. J. III, Santucci, J. V. J., and Wahl, D. H. (2003). Effects of adult common carp (Cyprinus carpio) on multiple trophic levels in shallow mesocosms. Canadian Journal of Fisheries and Aquatic Sciences 60 , 182-192. doi:10.1139/F03-011

Paukert, C. P., and Willis, D. W. (2003). Aquatic invertebrate assemblages in shallow prairie lakes: fish and environmental influences. Journal of Freshwater Ecology 18, 523-536. doi:10.1080/02705060.2003.9663993

Paukert, C. P., Willis, D. W., and Holland, R. S. (2002a). Sample size requirements for in situ vegetation and substrate classifications in shallow, natural Nebraska lakes. North American Journal of Fisheries Management 22, 1329-1333. doi:10.1577/1548-8675(2002)022<1329: $\mathrm{SSRFIS}>2.0 . \mathrm{CO} ; 2$

Paukert, C. P., Willis, D. W., and Klammer, J. A. (2002b). Effects of predation and environment on quality of yellow perch and bluegill populations in Nebraska sandhill lakes. North American Journal of Fisheries Management 22, 86-95. doi:10.1577/1548-8675(2002)022<0086:EOPAEO > 2.0.CO;2

Peterson, C. H. (1984). Does a rigorous criterion for environmental identity preclude the existence of multiple stable points? American Naturalist 124, 127-133. doi:10.1086/284256

Poff, N. L., Olden, J. D., Vieira, N. K., Finn, D. S., Simmons, M. P., and Kondratieff, B. C. (2006). Functional trait niches of North American lotic insects: traits-based ecological applications in light of phylogenetic relationships. Journal of the North American Benthological Society 25, 730-755. doi:10.1899/0887-3593(2006)025[0730:FTNONA]2.0.CO;2

Richardson, W., Wickham, S., and Threlkeld, S. (1990). Foodweb response to the experimental manipulations of a benthivore (Cyprinus carpio) zooplanktivore (Menidia beryllina) and benthic insects. Archiv für Hydrobiologie 119, 143-165

Ricker, W. E. (1975). 'Computation and Interpretation of Biological Statistics of Fish Populations.' (Department of the Environment, Fisheries and Marine Service: Ottawa, ON, Canada.) 
Scheffer, M., and Jeppesen, E. (1998). Alternative stable states. In 'Ecological Studies; the Structuring Role of Submerged Macrophytes in Lakes'. (Eds E. Jeppeson, M. Sondergaard, and K. Christoffersen.) pp. 397-406. (Springer-Verlag: New York.)

Scheffer, M., Hosper, S. H., Meijer, M. L., Moss, B., and Jeppesen, E. (1993). Alternative equilibria in shallow lakes. Trends in Ecology \& Evolution 8, 275-279. doi:10.1016/0169-5347(93)90254-M

Schmitz, O. J., Beckerman, A. P., and O'Brien, K. M. (1997). Behaviorally mediated trophic cascades: effects of predation risk on food web interactions. Ecology 78, 1388-1399. doi:10.1890/0012-9658(1997) 078[1388:BMTCEO]2.0.CO;2

Schmitz, O. J., Krivan, V., and Ovadia, O. (2004). Trophic cascades: the primacy of trait-mediated indirect interactions. Ecology Letters 7, 153-163. doi:10.1111/J.1461-0248.2003.00560.X

Schrage, L., and Downing, J. (2004). Pathways of increased water clarity after fish removal from Ventura Marsh; a shallow, eutrophic wetland. Hydrobiologia 511, 215-231. doi:10.1023/B:HYDR.0000014065.82229.C2

Simberloff, D. (1998). Flagships, umbrellas, and keystones: is single-species management passé in the landscape era? Biological Conservation 83, 247-257. doi:10.1016/S0006-3207(97)00081-5

Stein, R. A., DeVries, D. R., and Dettmers, J. M. (1995). Food-web regulation by a planktivore: exploring the generality of the trophic cascade hypothesis. Canadian Journal of Fisheries and Aquatic Sciences 52, 2518-2526. doi:10.1139/F95-842

Strong, D. R. (1992). Are trophic cascades all wet? Differentiation and donorcontrol in speciose ecosystems. Ecology 73, 747-754. doi:10.2307/ 1940154

van Donk, E., and van de Bund, W. J. (2002). Impact of submerged macrophytes including charophytes on phyto-and zooplankton communities: allelopathy versus other mechanisms. Aquatic Botany 72, 261-274. doi:10.1016/S0304-3770(01)00205-4

van Veen, F. J. F., and Sanders, D. (2013). Herbivore identity mediates the strength of trophic cascades on individual plants. Ecosphere 4, art64. doi:10.1890/ES13-00067.1
Vander Zanden, M. J., Cabana, G., and Rasmussen, J. B. (1997). Comparing trophic position of freshwater fish calculated using stable nitrogen isotope ratios $\left(\delta^{15} \mathrm{~N}\right)$ and literature dietary data. Canadian Journal of Fisheries and Aquatic Sciences 54, 1142-1158. doi:10.1139/F97-016

Vilizzi, L., Tarkan, A. S., and Copp, G. H. (2015). Experimental evidence from causal criteria analysis for the effects of common carp Cyprinus carpio on freshwater ecosystems: a global perspective. Reviews in Fisheries Science \& Aquaculture 23, 253-290. doi:10.1080/23308249. 2015.1051214

Wahl, D., Wolfe, M., Santucci, V., and Freedman, J. (2011). Invasive carp and prey community composition disrupt trophic cascades in eutrophic ponds. Hydrobiologia 678, 49-63. doi:10.1007/S10750-011-0820-3

Wanner, G. A. (2011). 2010 fisheries surveys Valentine National Wildlife Refuge, Nebraska. US Fish and Wildlife Service Report, Pierre, South Dakota.

Weber, M. J., and Brown, M. L. (2009). Effects of common carp on aquatic ecosystems 80 years after 'carp as a dominant': ecological insights for fisheries management. Reviews in Fisheries Science 17, 524-537. doi:10.1080/10641260903189243

Weier, J. L., and Starr, D. F. (1950). The use of rotenone to remove rough fish for the purpose of improving migratory waterfowl refuge areas. The Journal of Wildlife Management 14, 203-205. doi:10.2307/3796333

Wetzel, R. G., and Likens, G. E. (2000) 'Limnological Analyses', 3rd edn. (Springer-Verlag: New York.)

Wolfe, M. D., Santucci, V. J., Einfalt, L. M., and Wahl, D. H. (2009). Effects of common carp on reproduction, growth, and survival of largemouth bass and bluegills. Transactions of the American Fisheries Society 138, 975-983. doi:10.1577/T08-115.1

Wood, S. A., Karp, D. S., DeClerck, F., Kremen, C., Naeem, S., and Palm, C. A. (2015). Functional traits in agriculture: agrobiodiversity and ecosystem services. Trends in Ecology \& Evolution 30, 531-539. doi:10.1016/ J.TREE.2015.06.013 